\title{
EFFECT OF AN INCREMENTAL EXERCISE TO EXHAUSTION ON PLASMA CONCENTRATIONS OF IRON AND ZINC IN ATHLETES AND NONATHLETES
}

\author{
Daniel Tarmast \\ Department of Physical Education and Sport Sciences, Faculty of Humanities, Parand Branch, Islamic Azad \\ University, Parand city, Tehran, Iran
}

TYPE OF ARTICLE: ORIGINAL

\begin{abstract}
Background: Trace elements are mineral nutrients involved in a lot of physiological processes during exercise. Some of the trace elements, such as iron $(\mathrm{Fe})$ and zinc $(\mathrm{Zn})$ play a major function in maintaining and regulating many of these processes. The variations in plasma $\mathrm{Fe}$ and $\mathrm{Zn}$ concentrations are dependent which follow intensity as well as the duration of the activity. Endurance exercise until exhaustion causes various changes in the body. Deficiencies in $\mathrm{Fe}$ and $\mathrm{Zn}$ can harmfully influence endurance performance.

Objective: The purpose of the current study was to determine the effects of an incremental exercise until exhaustion on the plasma levels of $\mathrm{Fe}$ and $\mathrm{Zn}$ in athletes and nonathletes.

Methods: Ten elite basketball players (Age: $19.1 \pm 0.8$ years old, Height: $185.0 \pm 6.3 \mathrm{~cm}$, Weight: $71.0 \pm 9.8 \mathrm{~kg}$, VO2max: $59.5 \pm 7.3 \mathrm{~mL} \cdot \mathrm{kg}^{-1} \cdot \mathrm{min}^{-1}$ ) and ten college students (Age: $22.5 \pm 3.8$ years old, Height: $176.1 \pm 7.6 \mathrm{~cm}$, Weight: $67.8 \pm 11.4 \mathrm{~kg}, \mathrm{VO}_{2} \max : 33.1 \pm 8.4 \mathrm{~mL} \cdot \mathrm{kg}^{-1} \cdot \mathrm{min}^{-1}$ ) participated as athletes' group and control group respectively. All trials were conducted at the beginning of a competing season in one week for each group in the Ahvaz city, Khouzestan State, Islamic Republic of Iran. All participants completed 3 separate trials which consisted of maximal oxygen uptake test, a familiarization trial, and an actual trial. They pedaled an incremental exercise to exhaustion in the familiarization (without blood sampling) and actual trials. After a warm-up, the pedaling began on the ergometer at 100 watts and at $60 \mathrm{rpm}$. Then, the workload was increased gradually to 50 watts every two minutes until exhaustion. The blood samples were drawn three times after the actual trials. Statistical analyses were performed using the IBM SPSS v.25 for Windows.

Results: The results of the current study showed a significant decrease in Fe and $\mathrm{Zn}$ immediately and 24 hours after incremental exercise to exhaustion $(\mathrm{p}<0.05)$ in both groups. However, there were no significant differences between the two groups of athletes and nonathletes ( $p>0.05)$.

Conclusion: The current study concluded that exhaustive exercise was able to decrease the Fe and Zn status after exercise which may reflect the potential consequences for the dietary requirement of trace elements for physically active inhabitants.
\end{abstract}

KEYWORDS: Iron, Zinc, Trace Elements, Incremental Exercise, Exhaustion

\section{INTRODUCTION}

Many micronutrients play important functions in a variety of metabolic reactions during exercise which are able to affect the level of energy production $(1,2)$. Trace elements are mineral nutrients involved in the structure of many enzymes in the chemical processes that occur in all living organisms. Iron $(\mathrm{Fe})$ and Zinc $(\mathrm{Zn})$ are the two important trace elements required for health (3), and optimal exercise performance $(4,5)$. The conceptions of them are based on the following principles: primarily, during exercise athletes have a greater demand for various elements than less active individuals, in addition, that many athletes frequently do not ingest a sufficient diet plan concerning these two trace elements, thirdly, that this observed low ingestion of $\mathrm{Fe}$ and $\mathrm{Zn}$ can cause a reducing of peak athletic performance, and eventually will lead possibly to the occurrence of some disease situations (3). Most of the Fe found exists to proteins including hemoglobin, myoglobin, ferritin, and some enzymes (6). Fe excretion happens over the digestive tract, urinary system, cell turnover, and sweating $(4,7,8)$. During exercise, the Fe stores may be affected by the physiological changes that have negative consequences on the performance as well as on the health. There is evidence that the condition Fe stores in physically active people are negatively altered $(4,9,10)$. The $\mathrm{Fe}-$ binding proteins in the muscle and blood participate in the synthesis of ATP for muscle contraction during exercise

\section{Correspondence:}

Department of Physical Education and Sport Sciences, Faculty of Humanities, Parand Branch, Islamic Azad University, Parand city, Tehran, Iran. Tel: +982144361688; Email: danieltarmast@gmail.com

Received: January 28, 2019, Accepted: Agust 15, 2019, Published: September 2019

(C) 2019 The Authors. This is an open access article under the terms of the Creative Commons Attribution-NonCommercialNoDerivs License, which permits use and distribution in any medium, provided the original work is properly cited, the use is non-commercial and no modifications or adaptations are made. 
$(3,4,10)$. The oxygen-carrying capacity of the blood is the rate-limiting Fe-binding protein responsible for reduced exercise performance.

Sufficient $\mathrm{Fe}$ is required to produce healthy red blood cells, and prevent the fatigue associated with Fe-deficiency anemia. Few studies have shown anemia in male runners (1.2-5.7\%) and adolescent swimmers (6.7\%) (11-13). Prevalence of Fe deficiency anemia in male adolescents in Iran is 7.9\% (14). Previously published studies have shown remarkable reductions in ferritin level with exercise (15-18), whereas others have shown no significant change (9, 18-20). Recently, some studies have investigated the effects on Fe balance during short-term exercise. These studies clearly indicated that there is a significant decline in Fe stores in young men (18, 21-24). There are some physiological functions required sufficient amounts of other minerals like $\mathrm{Zn}$. Most of the concentration of $\mathrm{Zn}$ of about $2 \mathrm{~g}$ is found in muscle $(60 \%)$, bone $(30 \%)$, liver, and kidney $(5,25)$. This important trace element holds biological functions in the metabolism of macronutrients, thus $\mathrm{Zn}$ is necessary for exercise performance (3, 4). Insulin secretion needs $\mathrm{Zn}$ as do many enzymes, and this hormone modifies the metabolism of carbohydrates and fats (26). Hence, the status of $\mathrm{Zn}$ has an impact on energy substrate utilization during exercise. $\mathrm{Zn}$ is found everywhere in cellular metabolism, and is an important constituent of the catalytic sites of at least one enzyme in each of the six major classes of enzymes (27-29). In athletes with an average Zn intake of 10 to $14 \mathrm{mg} / \mathrm{d} \mathrm{more}$ than $90 \%$ of dietary $\mathrm{Zn}$ is excreted in the feces (30), and rest of the $10 \%$ is lost via other ways of $\mathrm{Zn}$ excretion from skin and urine (31). Surface losses from the skin, sweat, and hair, provide up to $1 \mathrm{mg} / \mathrm{d}$ of $\mathrm{Zn}$ loss (31). These amounts of $\mathrm{Zn}$ losses from the skin and urine as well as an inflammatory response to exercise may account for the concern of many athletes $(32,33)$. Couzy et al. (1990) showed that intensive training significantly declined the serum concentration of $\mathrm{Zn}$ (25). Also, Manore et al. (1993) revealed that there was a significant decrease in plasma $\mathrm{Zn}$ following 6 weeks of an aerobic exercise program (34). In a meta-analysis Chu et al. (2018) verified that the serum Zn concentrations were considerably reduced in athletes as compared to controls, although athletes consumed a higher $\mathrm{Zn}$ diet plan (35). Their systematic review shows that $\mathrm{Zn}$ homeostasis probably is affected in athletes, showing that athletes require a higher amount of $\mathrm{Zn}$ as compared to those that are less active.

Athletes' diet plan during high-performance exercise could be altered to a considerable amount from the suggested diet for the general population. The trace elements of the current study, Fe and $\mathrm{Zn}$ are nutritionally important micronutrients for exercise performance. Fe and $\mathrm{Zn}$ deficiencies have been reported in clinical and population investigations, although the prevalence is difficult to quantify by reason of the limited studies on $\mathrm{Zn}$ status in exercise. This study, therefore, was set out to assess the effects of an incremental exercise until exhaustion on the plasma concentrations of $\mathrm{Fe}$ and $\mathrm{Zn}$ on athletes and subjects that have no exercise in regular program training.

\section{MATERIALS AND METHODS}

\subsection{Research Design}

To determine the influences of an incremental exercise to exhaustion on Fe and Zn plasma concentrations in athletes and nonathletes, a controlled study design with repeated measures (i.e., pre, post) was used. The trials were completed by two groups of athletes and sedentary subjects who were assigned as the athletes and nonathletes groups respectively. Trace elements of the current study were measured as a pre-test blood sampling before the incremental exercise, subsequently a three-post-test blood sampling were drawn after the exercise.

\subsection{Selection Criteria}

The study was carried out at the beginning of the competition season when the athletes were physically ready for their recent event. The basketball players were the athlete's group those who had been training regularly 3 sessions per week for three years. In addition, some of them have been selected to participate in the Iranian Basketball Super League and Iranian national training camps. Melli Haffari basketball team from Ahvaz city with 35 players were selected as the athlete group. The college students were studying at Chamran University of Ahvaz who were sedentary individuals assigned for the nonathletes group of the study. For the nonathletes group, 41 sedentary subjects were invited to participate in familiarization trials. The inclusion criteria were, requiring no history of medication at least for last three weeks before the study, being non-smoker, free of renal, thyroid, diabetes, liver, cardiovascular diseases as indicated by their medical history, and aged 17 to 25 years old. The subjects were not taking dietary any required treatments or supplementations and instructed to not change current dietary behaviors. All of them had been living in the same state of Khouzestan, Iran for at least two years prior to the beginning of the study. 


\subsection{Subjects}

Ten male state basketball players (Age: $19.1 \pm 0.8$ years old, Height: $185.0 \pm 6.3 \mathrm{~cm}$, Weight: $71.0 \pm 9.8 \mathrm{~kg}, \mathrm{VO}_{2} \max$ : $59.5 \pm 7.3 \mathrm{~mL} \cdot \mathrm{kg}^{-1} \cdot \mathrm{min}^{-1}$ ) and ten male college students (Age: $22.5 \pm 3.8$ years old, Height: $176.1 \pm 7.6 \mathrm{~cm}$, Weight: $67.8 \pm 11.4 \mathrm{~kg}, \mathrm{VO}_{2} \max : 33.1 \pm 8.4 \mathrm{~mL} \cdot \mathrm{kg}^{-1} \cdot \mathrm{min}^{-1}$ ) that had no practical experience in any sports programs were recruited to participate in this study. The physical characteristics of the participants are illustrated in Table 1 that is based on the two groups of the study. All subjects were informed about the purpose and scope of the current study as well as the potential benefits and risks associated with research participation, and signed an informed written consent before the start of the study. The study was approved by the Ethics Committee of the Faculty of Physical Education and Sports Sciences, Central Tehran Branch, Islamic Azad University.

Table 1. The physical characteristics of the participants $(n=20)$.

\begin{tabular}{|l|l|l|}
\hline Variables, Mean \pm SD & Athletes $(\mathrm{n}=10)$ & Nonathletes $(\mathrm{n}=10)$ \\
\hline Age $($ year $)$ & $19.1 \pm 0.8$ & $22.5 \pm 3.8$ \\
\hline Height $(\mathrm{cm})$ & $185.0 \pm 6.3$ & $176.1 \pm 7.6$ \\
\hline Weight $(\mathrm{kg})$ & $71.0 \pm 9.8$ & $67.8 \pm 11.4$ \\
\hline Body Mass Index $\left({\left.\mathrm{kg} . \mathrm{m}^{-2}\right)}^{-1}\right)$ & $19.3 \pm 1.1$ & $20.6 \pm 1.2$ \\
\hline $\mathrm{VO}_{2}$ max $\left(\mathrm{mL}_{\mathrm{kg}}{ }^{-1} \mathrm{~min}^{-1}\right)$ & $59.5 \pm 7.3$ & $33.1 \pm 8.4$ \\
\hline Training Experience $(\mathrm{year})$ & $2.9 \pm 0.9$ & 0 \\
\hline Heart Rate at Rest $(\mathrm{bpm})$ & $64.1 \pm 4.1$ & $85.4 \pm 7.1$ \\
\hline Maximal Heart Rate $(\mathrm{bpm})$ & $191.0 \pm 9.8$ & $183.6 \pm 8.3$ \\
\hline Maximal Workload (w) & $260.0 \pm 20.1$ & $131 \pm 23.4$ \\
\hline Maximal Cadence (rpm) & $130.6 \pm 28.2$ & $95.7 \pm 15.2$ \\
\hline The Ratings of Perceived Exertion (Borg's Unit) & $17.5 \pm 9.4$ & $18.1 \pm 5.4$ \\
\hline Trial Duration (min:sec) & $07: 41 \pm 00: 02$ & $02: 45 \pm 00: 40$ \\
\hline
\end{tabular}

\subsection{Procedures}

All participants underwent three separate trials which were conducted at Khouzestan Championship Camp Center in Ahvaz city. The first trial was a maximal trial on an ergometer (Technogym ${ }^{\circledR}$ BIKE FORMA, Italy) to estimate the maximal oxygen uptake $\left(\mathrm{VO}_{2} \mathrm{max}\right)$ by using the Astrand-Ryhming nomogram $(6,36)$. Each participant of the study pedaled a trial of approximately 6 minutes, trying a heart rate monitor (Oy, Kempele, Finland) between 125 and 170 beats.min-1. According to the participant's heart rate response to the 6-minute pedaling, the $\mathrm{VO}_{2}$ max was predicted. This prediction was used to recruit participants with a higher value of $\mathrm{VO} 2 \mathrm{max}$ that the accepted range for them was between 40 and 60 , and $>40 \mathrm{~mL} . \mathrm{kg}-1 . \mathrm{min}-1$ for the basketball players and nonathletes respectively (37). In the second visit, all participants participated in a familiarization trial. This trial was an incremental exercise to exhaustion that was similar to the actual trial, but with no blood sampling. Based on the results of the VO2max predictions and familiarization trials, ten basketball players, and ten nonathletes were invited to participate in the actual trials as the athletes' group and nonathletes' group respectively. Three days later, both groups performed an actual trial in the morning that was an incremental exercise to exhaustion (38). In this trial, participants were asked to pedal on the same ergometer of familiarization trial at $60 \mathrm{rpm}$ (revolutions per minute) cadence for 3 minutes to warm-up without any workload. Before the warm-up, their height and nude body weight were measured individually by using a stadiometer and a scale in the changing room of the camp. In addition, about $5 \mathrm{~mL}$ of venous blood was drawn by a laboratory technician from participants as the first blood sampling. After 1 minute, the pedaling began on the ergometer at 100 watts $(\mathrm{w})$ and at $60 \mathrm{rpm}$. Then, the workload was increased gradually at 50 $\mathrm{w}$ every two minutes until exhaustion. During the actual trial, the participants were given intense verbal encouragement to continue the pedaling for as long as possible, especially once the cadence dropped towards $60 \mathrm{rpm}$ (39). Time to exhaustion was recorded to the nearest second, and it was ordained when the pedaling first fell below $60 \mathrm{rpm}$, or maximal heart rate of less than $15 \mathrm{bpm}$ lower than age-predicted maximum heart rate (220-age) (40). Participants were not informed of any details concerning their performance during or after trials until all data collection had been finished. After the actual trial, the participants were asked to sit down or walk slowly for 15 min. Meanwhile, the second blood sample was taken immediately after the trial. The third and fourth blood samples were drawn 24 and 48 hours respectively after the end of the actual trials. The heart rate and ratings of perceived exertion (RPE; Borg's scale, 1998) were recorded every 30 seconds during the actual trial (6). The workload, cadence, and time of the pedaling were recorded at the end of the actual trials. To monitor the diet of the participants, all of them were asked to refrain from consuming any supplements that comprise $\mathrm{Fe}$ and $\mathrm{Zn}$ during this study period. They were also asked to refrain from vigorous training 24 hours prior to each trial. A food diary form was given to each 
participant to document their diet three days prior to each trial (41). Then, they were requested to repeat the same diet plan over three days.

\subsection{Trace Elements Blood Analysis}

After the blood collections, samples were centrifuged at $4{ }^{\circ} \mathrm{C}$ for $15 \mathrm{~min}$ at $3000 \mathrm{rpm}$ to separate the blood plasma. Plasma samples were kept at $-80^{\circ} \mathrm{C}$ until for analyzing. Plasma samples were diluted using $1 \%$ nitric acid (Merck Chemicals Ltd), and then investigated for Fe and $\mathrm{Zn}$ using air-acetylene flame atomic absorption spectrophotometer using hollow cathode lamps (Thermo electron corporation, UK). In this study, the determination of Fe and $\mathrm{Zn}$ was done by wavelengths of 248.3 and $213.9 \mathrm{~nm}$ for Fe and $\mathrm{Zn}$ respectively.

\subsection{Statistical Analysis}

Statistical analyses were performed using the IBM SPSS v.25 for Windows. The results are expressed as mean and standard deviation (mean $\pm \mathrm{SD}$ ). The normal distribution of the variables was assessed using the KolmogorovSmirnov test, and Leven's test for homogeneity. The significant differences of trace elements between groups of athletes and nonathletes were determined by one-way ANOVA followed by a LSD post-hoc test. To determine the differences in trace elements' plasma changes associated with two groups of athletes and nonathletes, analysis of variance (ANOVA) with repeated measurement was used. The level of statistical significance was set at $p<0.05$.

\section{RESULTS}

The distribution of the dependent variables of Fe and $\mathrm{Zn}$ plasma concentrations in each combination of the related groups of athletes and nonathletes based on results of the Kolmogorov-Smirnov test (Table 2) are approximately normally distributed $(\mathrm{p}>0.05)$. It can be seen from the data in Figure 1 that the plasma concentrations of Fe and $\mathrm{Zn}$ in athletes and nonathletes changed over time. -The plasma Fe concentrations in the athlete group significantly decreased as compared to the baseline levels immediately after the trial $(\mathrm{p}=0.002)$, and at 24 hours after the incremental exercise to exhaustion $(\mathrm{p}=0.006)$. But, there was no significant difference at 48 hours after the incremental exercise to exhaustion $(\mathrm{p}=0.642)$ as compared to the baseline level. However, no significant differences in the nonathletes group were found between the baseline levels and immediately after the trial $(p=0.221)$, and at 24 $(p=0.152)$ and $48(p=0.127)$ hours after the incremental exercise to exhaustion (Table 3$)$.

Table 2. The normality by the Kolmogorov-Smirnov test $(n=20)$.

\begin{tabular}{|l|l|l|l|l|}
\hline Variables & Blood samplings & Statistics & df & Sig. \\
\hline Iron in Athletes & Baseline level & .260 & 10 & .063 \\
\cline { 2 - 5 } & Immediately after trial & .221 & 10 & .182 \\
\cline { 2 - 5 } & $24 \mathrm{hr}$ after trial & .163 & 10 & .200 \\
\cline { 2 - 5 } & $48 \mathrm{hr}$ after trial & .240 & 10 & .109 \\
\hline Iron in Nonathletes & Baseline level & .174 & 10 & .200 \\
\cline { 2 - 5 } & Immediately after trial & .165 & 10 & .200 \\
\cline { 2 - 5 } & $24 \mathrm{hr}$ after trial & .111 & 10 & .200 \\
\cline { 2 - 5 } & $48 \mathrm{hr}$ after trial & .159 & 10 & .200 \\
\hline Zinc in Athletes & Baseline level & .205 & 10 & .200 \\
\cline { 2 - 5 } & Immediately after trial & .158 & 10 & .200 \\
\cline { 2 - 5 } & $24 \mathrm{hr}$ after trial & .143 & 10 & .200 \\
\cline { 2 - 5 } & $48 \mathrm{hr}$ after trial & .162 & 10 & .200 \\
\hline Zinc in Nonathletes & Baseline level & .182 & 10 & .200 \\
\cline { 2 - 5 } & Immediately after trial & .161 & 10 & .200 \\
\cline { 2 - 5 } & $24 \mathrm{hr}$ after trial & .198 & 10 & .200 \\
\cline { 2 - 5 } & $48 \mathrm{hr}$ after trial & .212 & 10 & .200 \\
\hline
\end{tabular}




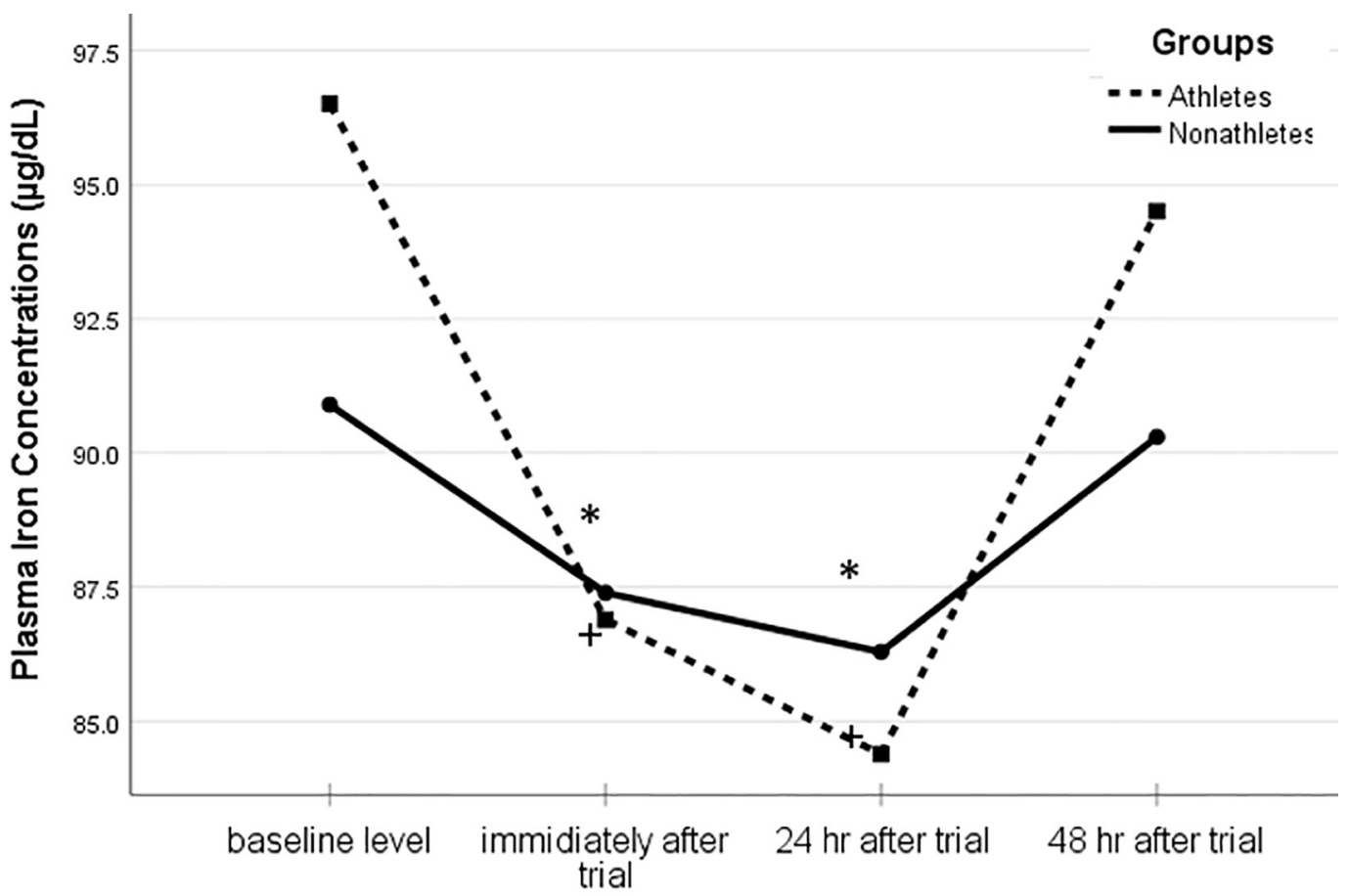

Figure 1. The plasma iron levels of the participants at baseline, immediately after the incremental exercise to exhaustion, 24 and 48 hours after the end of the actual trials. * Significantly different from the baseline values in athletes' group $(\mathrm{p}<0.05)$. + Significantly different from the baseline values in nonathletes' group $(\mathrm{p}<0.05)$.

Table 3. The multiple comparisons of mean differences and significances.

\begin{tabular}{|l|l|l|l|l|l|}
\hline Dependent Variable & \multicolumn{2}{|l|}{ Blood Sampling } & Mean Difference & Std. Error & Sig. \\
\hline Iron Changes in Athletes & \multirow{2}{*}{ Baseline level } & Immidiately after trial & 9.600 & & \\
\cline { 3 - 6 } & & $24 \mathrm{hr}$ after trial & 12.100 & 4.7 & .002 \\
\cline { 3 - 6 } & & $48 \mathrm{hr}$ after trial & 2.000 & .006 \\
\hline Iron Changes in Nonathletes & \multirow{2}{*}{ Baseline level } & Immidiately after trial & 3.500 & 4.7 & .642 \\
\cline { 3 - 6 } & & $24 \mathrm{hr}$ after trial & 4.600 & 3.8 & .221 \\
\cline { 3 - 6 } & & $48 \mathrm{hr}$ after trial & .600 & 3.8 & .152 \\
\hline Zinc Changes in Athletes & \multirow{2}{*}{ Baseline level } & Immidiately after trial & 1.300 & 3.8 & .127 \\
\cline { 3 - 6 } & & $24 \mathrm{hr}$ after trial & 7.300 & 5.5 & .045 \\
\cline { 3 - 6 } & & $48 \mathrm{hr}$ after trial & .600 & 5.5 & .023 \\
\hline Zinc Changes in Nonathletes & \multirow{2}{*}{ Baseline level } & Immidiately after trial & 5.900 & 6.5 & .439 \\
\cline { 3 - 6 } & & $24 \mathrm{hr}$ after trial & 10.400 & 6.8 & .022 \\
\cline { 3 - 6 } & & $48 \mathrm{hr}$ after trial & 3.600 & 6.8 & .067 \\
\hline
\end{tabular}

The results obtained from the plasma concentrations of $\mathrm{Zn}$ for both groups are presented in Figure 2. This figure shows that immediately after the incremental exercise to exhaustion the plasma $\mathrm{Zn}$ concentrations did not change significantly when compared to the baseline amounts in the athlete group $(\mathrm{p}=0.361)$. But, it was significantly declined after 24 hours after the trial $(\mathrm{p}=0.050)$. While, after 48 hours of the incremental exercise to exhaustion it reached to the baseline amounts $(\mathrm{p}=0.813)$. The plasma $\mathrm{Zn}$ concentrations in the nonathletes group reduced immediately after the incremental exercise to exhaustion $(\mathrm{p}=0.045)$. Also, this reduction was significant at 24 hours after the trial $(\mathrm{p}=0.023)$.Then, it was increased at 48 hours after the incremental exercise to exhaustion $(\mathrm{p}=0.439)$ (Table 3). No significant differences were found between the two groups in the trace elements' concentrations at any point of time ( $p>0.05)$. Strong evidence of Fe and $\mathrm{Zn}$ changes was found when both groups of the current study participated in the incremental exercise to exhaustion. 


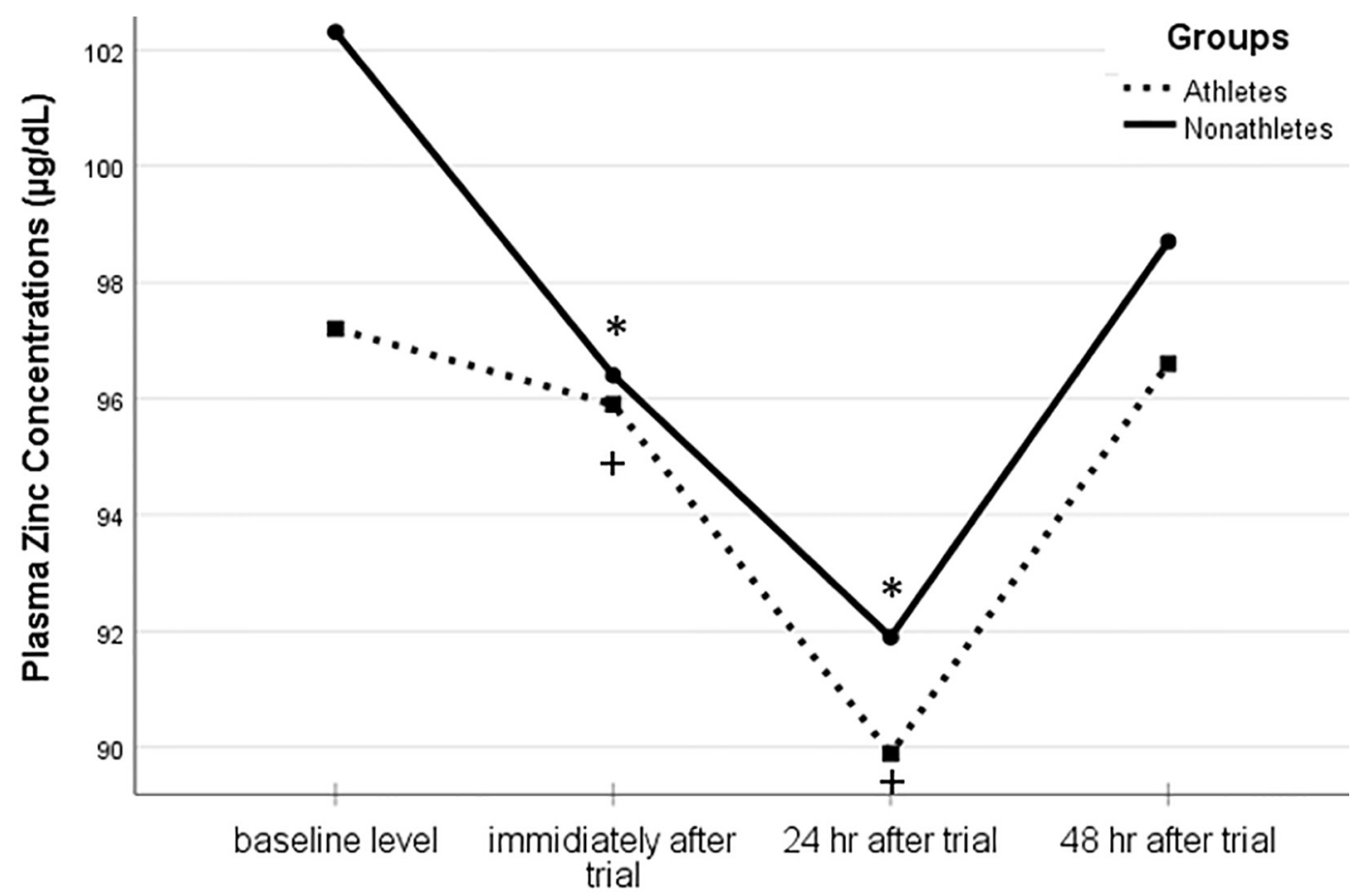

Figure 2. The plasma zinc levels of the participants at baseline, immediately after the incremental exercise to exhaustion, 24 and 48 hours after the end of the actual trials. * Significantly different from the baseline values in athletes' group $(\mathrm{p}<0.05)$. + Significantly different from the baseline values in nonathletes' group $(\mathrm{p}<0.05)$.

\section{DISCUSSION}

In the current study, the plasma concentrations of $\mathrm{Fe}$ and $\mathrm{Zn}$ as two important trace elements were studied in athletes and nonathletes. Trace elements support critical functions in the body to secure the normal metabolism and homeostasis. Previously published studies on the effect of exercise are not consistent on the trace elements which deficiencies and excesses in any of them can result in the appearance of some disorders (42-44). Additionally, the blood changes in trace elements have been detected to have a role as indices of serious mood disorders such as depression in adolescents (45). Therefore, tracking the amounts of the trace elements of $\mathrm{Fe}$ and $\mathrm{Zn}$ as the two important trace elements in the body could be beneficial indices in the prevention of these disorders. There were reductions in the plasma concentrations of $\mathrm{Fe}$ and $\mathrm{Zn}$ from baseline to the after of the incremental exercise to exhaustion. These results are in accord with recent studies indicating that the Fe stores were significantly decreased after exercise in men $(18,21-24)$. In addition, the results are consistent with other studies which found the $\mathrm{Zn}$ reductions after exercise $(25,34,35)$. However, the plasma concentrations of $\mathrm{Fe}$ and $\mathrm{Zn}$ were reached to the baseline after 48 hours of the incremental exercise to exhaustion. Furthermore, these changes of the trace elements of Fe and $\mathrm{Zn}$ were in the normal range for men.

It is now well established from a variety of studies that the low levels of the Fe status in athletes and other physically active populations effect on exercise performance $(3,4,22,46)$. Fe, in both forms of heme or a Fe-sulfur compound holds a wide variety of physiological roles in the body. One of the vital parts of the hemoglobin is Fe which is responsible for the transportation of oxygen and carbon dioxide in the blood. This trace element is available in muscle as a myoglobin constituent which derives oxygen from hemoglobin molecules, operates as an antioxidant, and is an important part of the electron transport chain for the ATP synthesis. Most of the ATP releasing in longterm activities are produced by oxidative pathways. Hence, it is possible in cellular respiration some proteins that are comprised of Fe could restrict factors of energy production in iron deficit and harm the performance rather than the glycolysis. The degradation capacity of performance while the iron is not sufficient in the endurance athletes' body is associated with myoglobin, cytochrome oxidase, and mitochondrial NADH dehydrogenase.

In order to support the normal values of the Fe in the body the metabolism, conservation, recycling, and disposal of $\mathrm{Fe}$ involves a normal balance within the body. The consequence of enhanced exercise on Fe homeostasis in athletes leads to the reduction of Fe status. In the 1970s, some authors described reducing hemoglobin levels in athletes who 
were being involved in the exercise $(47,48)$, and other studies found that gastrointestinal bleeding (49), hematuria (50), and Fe excretions in sweat (8) were the important reasons for the reduced levels of hemoglobin. However, this reduction is able to diminish the capacity of oxygen-carrying and maximal oxygen uptake (VO2max), affecting exercise performance (51). Likewise, another study has shown a linear relationship between hemoglobin levels, the percentage increase in heart rate, and blood lactate levels in response to an exercise trial (52). Another important protein that in the muscles is in charge of oxygen transport and storage is myoglobin. A considerable amount of literature has been published on myoglobin. These studies have confirmed decreases in myoglobin in skeletal muscle happening with reduced $\mathrm{Fe}$ status (53). Finch et al. (1976) explained an association between reductions in myoglobin and reduced exercise performance (54). Therefore, the reduced levels of hemoglobin and myoglobin in athletes could be a major factor, if not the only one, causing the exercise performance impairment as discussed above. Further, than the effects of reduced $\mathrm{Fe}$ status on exercise performance, athletes and other individuals who engage in exercise should be aware of reductions in Fe status related to exercise.

A number of authors have considered the effects of exercise on the $\mathrm{Zn}$ status in athletes $(4,10,30,42,55)$. The early concern between exercise and $\mathrm{Zn}$ status was caused due to a report of a drop in the $\mathrm{Zn}$ blood levels in athletes as compared with nonathletes (56). Cordova et al. (1998) demonstrated that altered $\mathrm{Zn}$ metabolism coupled with enhanced $\mathrm{Zn}$ excretion and stress levels resulted in fatigue sensation and reduced performance (57). Several systematic reviews of the changes of this trace element in exercise have been undertaken. Recently, a systematic review by $\mathrm{Chu}$ et al. (2017) showed that blood $\mathrm{Zn}$ changes are lesser in the athletes' group when compared with the controls (29). In another systematic review by Chu et al. (2018) they collated Zn status evidence from other studies (35). They realized a significant decrease in the blood levels of $\mathrm{Zn}$ in athletes once compared to nonathletes, showing that the homeostasis of $\mathrm{Zn}$ might be different in athletes. Their reviews concluded that athletes possibly demand higher $\mathrm{Zn}$ levels as compared to those individuals who are not active. Additionally, some studies have indicated lower blood $\mathrm{Zn}$ levels in athletes $(58,59)$. The results of the current study are in accord with recent studies indicating that athletes had a lower Zn plasma concentration when compared to the nonathletes despite the nonsignificant difference between the groups. There are some possible explanations for such reductions. However, different reasons may alter $\mathrm{Zn}$ homeostasis and requirements in athletes include inflammatory response to exercise, refrain from animal products, increased urinary, and sweat $\mathrm{Zn}$ losses $(3,4,27,30,33,58)$. The impairment in the metabolic regulation of leptin when $\mathrm{Zn}$ is deficient in exercise, as this is a protein produced by fatty tissue, it would be the rate-limiting factor in energy expenditure. Generally, a higher viscometric erythrocyte rigidity index happens in athletes once the $\mathrm{Zn}$ concentrations reduced during exercise. Subsequently, the power output of those athletes in exercise will be lowered, and the blood lactate will be increased during exercise, resulting in a reduced lactate threshold.

Supplementations of different trace elements have been verified to improve exercise performance (5). Van Loan et al. (1999) and Lukaski (2005) described the negative effects of ingesting lower $\mathrm{Zn}$ diet plans on exercise performance in carefully controlled human trials $(60,61)$. Similar to $\mathrm{Zn}$, some authors studied the Fe supplementations in athletes that may improve performance. Most of them summarized that athletes with a normal range of Fe status seem to be having no benefits of the Fe supplementations beyond recommended amounts for additional exercise benefits (4). Furthermore, harmful consequences can be related to excessive Fe consumption which is able to hinder the $\mathrm{Zn}$ absorption as a result of their similar physical and chemical features $(62,63)$. Solomons (1986) recommended that competitive interactions between Fe and $\mathrm{Zn}$ can happen once the total amount of the two trace elements in a diet plan goes above $25 \mathrm{mg}(63)$. In general, there is a negative influence of $\mathrm{Fe}$ on $\mathrm{Zn}$ absorption has been informed to appear while the Fe/Zn ratio is equal to, or exceeds two. It has been shown that there is also an inverse relationship between dietary Fe supplementation and blood $\mathrm{Zn}$ levels (63). Despite the monitoring diet plan of the participants via a food diary form, but nutrition assessments of trace elements were not the aim of the current study. Fe and $\mathrm{Zn}$ supplementations have been shown to improve endurance performance and muscle strength respectively. Hence, according to possible interactions that are able to happen among $\mathrm{Fe}$ and $\mathrm{Zn}$, and the point that some athletes can already be debatable relating to the $\mathrm{Zn}$ status, the possible negative impacts of additional Fe ingestion must be clear. The recommended amount of Fe supplement is $15 \mathrm{mg}$ per day to decrease their potential impacts on $\mathrm{Zn}$ absorption. Furthermore, the amount of $\mathrm{Zn}$ in the supplement is suggested not to be more than $15 \mathrm{mg}$ per day. However, the results of the different studies are inconclusive so that the consumption of $\mathrm{Zn}$ supplements at this time would not be suggested for athletic activities. Considerably more clinical investigations will require to be studied to determine the effects of exercise and trace elements of $\mathrm{Fe}$ and $\mathrm{Zn}$ on each other. 


\section{STUDY LIMITATIONS}

There are several possible explanations for the result of the current study. However, these results may be slightly limited by different factors that the researchers could not control them. The sample size was one of the limitations of this study. The short time of the data collection was another limiting factor to this study. All of the subjects who were invited from the Chamran University of Ahvaz or the Melli Haffari basketball team required to travel due to their personal life. In addition, the lack of previous studies in the research area is another limitation. This would be rather a generalized element to the larger populations. However, the implementation of data collection in the methodology could be the other limiting factor. Furthermore, during the familiarization trials, nonathletes indicated that the need for more guidance regarding the methodology and the incremental exercise to exhaustion

\section{CONCLUSIONS}

This study confirms that the two trace elements of $\mathrm{Fe}$ and $\mathrm{Zn}$ are associated with an incremental exercise to exhaustion. Athletes involved in fatiguing training and nonathletes engaging in unaccustomed training present indications of $\mathrm{Fe}$ and $\mathrm{Zn}$ reductions after exercise, and there is evidence of lower blood levels of these trace elements were able to impair exercise performance. Therefore, athletes and nonathletes should attempt to ingest a rich-diet plan of Fe and $\mathrm{Zn}$ in an effort to meet physiological demands during exhaustive exercise. Finally, there is growing attention in trace elements malnutrition, and some athletes are at risk of Fe and $\mathrm{Zn}$ deficiencies if they follow an unbalanced diet plan. Further studies of Fe and $\mathrm{Zn}$ homeostasis during and after exercise are necessary to explain the interaction between blood $\mathrm{Fe}$ and $\mathrm{Zn}$ responses and characteristics of specific exercise and individuals.

\section{ACKNOWLEDGMENTS:}

This article was obtained from Mr. Daniel Tarmast thesis in M.Sc. of Physical Education and Sport Sciences who is working as a senior lecturer. The author expresses his special thanks to the Deputy of Research of Islamic Azad University, Tehran Central Branch, Tehran, Iran, and Khouzestan Championship Camp Center at Ahvaz city, Khouzestan State, Iran. In addition, he would like to thank the authorities, the students and the basketball players who agreed to contribute and had enough patience in the current study. This study was not funded by any authorities.

\section{CONFLICT OF INTEREST:}

The author declares that he has no conflict of interests.

\section{REFERENCES:}

1) Maughan RJ. Role of micronutrients in sport and physical activity. British medical bulletin. 1999;55(3):683-90. Epub 2000/04/04. doi: 10.1258/0007142991902556. PMID: 10746356; PMCID: PMC10746356.

2) Sureda A, Bibiloni MDM, Julibert A, Aparicio-Ugarriza R, Palacios-Le Ble G, Pons A, et al. Trace element contents in toenails are related to regular physical activity in older adults. PloS one. 2017;12(10):e0185318. Epub 2017/10/07. doi: 10.1371/journal.pone.0185318. PMID: 28985222; PMCID: PMCPMC5630118.

3) McDonald R, Keen CL. Iron, zinc and magnesium nutrition and athletic performance. Sports Medicine. 1988;5(3):171-84. Epub 1988/03/01. doi: 10.2165/00007256-198805030-00004. PMID: 3285436.

4) McClung JP. Iron, Zinc, and Physical Performance. Biological Trace Element Research. 2018:1 -5. doi: 10.1007/s12011-018-1479-7. PMCID: PMC30112658.

5) Vincent JB, Neggers Y, McClung J. Roles of Chromium (III), Vanadium, Iron, and Zinc in Sports Nutrition. In: Bagchi D, Nair S, Sen CK, editors. Nutrition and Enhanced Sports Performance. 2nd ed: Elsevier; 2019. p. 653-64.

6) Howley ET, Powers SK. Exercise Physiology: Theory and Application to Fitness and Performance. 10th ed: McGraw-Hill Education; 2017.

7) Antonio J, Kalman D, Stout JR, Greenwood M, Willoughby DS, Haff GG. Essentials of sports nutrition and supplements. 1 ed: Humana Press; 2009.

8) Brune M, Magnusson B, Persson H, Hallberg L. Iron losses in sweat. The American journal of clinical nutrition. 1986;43(3):438-43. Epub 1986/03/01. doi: 10.1093/ajcn/43.3.438. PMID: 3953482.

9) Burden RJ, Morton K, Richards T, Whyte GP, Pedlar CR. Is iron treatment beneficial in, iron-deficient but non-anaemic (IDNA) endurance athletes? A systematic review and meta-analysis. British journal of sports medicine. 2015;49(21):1389-97. Epub 2014/11/02. doi: 10.1136/bjsports-2014-093624. PMID: 25361786.

10) Lee N. A Review of Magnesium, Iron, and Zinc Supplementation Effects on Athletic Performance. The Korean Journal of Physical Education. 2017;56(1):797-806. doi: 10.23949/kjpe.2017.01.56.1.59. 
11) Balaban EP, Cox JV, Snell P, Vaughan RH, Frenkel EPJM, sports si, et al. The frequency of anemia and iron deficiency in the runner. Medicine and science in sports and exercise. 1989;21(6):643-8. PMCID: PMC2626086.

12) Colt E, Heyman B. Low ferritin levels in runners. The Journal of Sports Medicine and Physical Fitness. 1984;24(1):13-7. PMCID: PMC6471833.

13) Rowland TW, Kelleher JF. Iron deficiency in athletes: insights from high school swimmers. American Journal of Diseases of Children. 1989;143(2):197-200. doi: 10.1001/archpedi.1989.02150140087026. PMCID: PMC2916491.

14) Akbari M, Moosazadeh M, Tabrizi R, Khatibi SR, Khodadost M, Heydari ST, et al. Estimation of iron deficiency anemia in Iranian children and adolescents: a systematic review and meta-analysis. Hematology. 2017;22(4):231-9. doi: 10.1080/10245332.2016.1240933.

15) Fogelholm MJijosn. Indicators of vitamin and mineral status in athletes' blood: a review. International Journal of Sport Nutrition. 1995;5(4):267-84. doi: 10.1123/ijsn.5.4.267.

16) Oh S, Tanaka K, Warabi E, Shoda J. Exercise reduces inflammation and oxidative stress in obesity-related liver diseases. Medicine and science in sports and exercise. 2013;45(12):2214-22. Epub 2013/05/24. doi: 10.1249/MSS.0b013e31829afc33. PMID: 23698242; PMCID: PMC23698242.

17) Schmidt W, Maassen N, Tegtbur U, Braumann K. Changes in plasma volume and red cell formation after a marathon competition. European journal of applied physiology. 1989;58(5):453-8. doi: 10.1007/BF02330696. PMCID: PMC2759069.

18) Deruisseau KC, Roberts LM, Kushnick MR, Evans AM, Austin K, Haymes EM. Iron status of young males and females performing weight-training exercise. Medicine and science in sports and exercise. 2004;36(2):241-8. Epub 2004/02/10. doi: 10.1249/01.Mss.0000113483.13339.7b. PMID: 14767246.

19) Clement DB, Lloyd-Smith DR, Macintyre JG, Matheson GO, Brock R, Dupont M. Iron status in Winter Olympic sports. Journal of sports sciences. 1987;5(3):261-71. Epub 1987/01/01. doi: 10.1080/02640418708729781. PMID: 3453407.

20) Moore RJ, Friedl KE, Tulley RT, Askew EW. Maintenance of iron status in healthy men during an extended period of stress and physical activity. The American journal of clinical nutrition. 1993;58(6):9237. Epub 1993/12/01. doi: 10.1093/ajcn/58.6.923. PMID: 8249880.

21) Schobersberger W, Tschann M, Hasibeder W, Steidl M, Herold M, Nachbauer W, et al. Consequences of 6 weeks of strength training on red cell O2 transport and iron status. European Journal of Applied Physiology and Occupational Physiology. 1990;60(3):163-8. doi: 10.1007/BF00839152. PMCID: PMC2347315.

22) Terink R, Ten Haaf D, Bongers CWG, Balvers MGJ, Witkamp RF, Mensink M, et al. Changes in iron metabolism during prolonged repeated walking exercise in middle-aged men and women. European journal of applied physiology. 2018;118(11):2349-57. Epub 2018/09/01. doi: 10.1007/s00421-018-3961-5. PMID: 30167958; PMCID: PMCPMC6182319.

23) Bauer P, Zeissler S, Walscheid R, Frech T, Hillebrecht A. Acute effects of high-intensity exercise on hematological and iron metabolic parameters in elite male and female dragon boating athletes. The Physician and sportsmedicine. 2018;46(3):335-41. Epub 2018/05/31. doi: 10.1080/00913847.2018.1482187. PMID: 29847191.

24) Lukaski HC, Bolonchuk WW, Siders WA, Milne DB. Chromium supplementation and resistance training: effects on body composition, strength, and trace element status of men. The American journal of clinical nutrition. 1996;63(6):954-65. doi: 10.1093/ajcn/63.6.954.

25) Couzy F, Lafargue P, Guezennec CY. Zinc metabolism in the athlete: influence of training, nutrition and other factors. International journal of sports medicine. 1990;11(4):263-6. Epub 1990/08/01. doi: 10.1055/s2007-1024804. PMID: 2228354.

26) Reeves PG, O'Dell BL. The effect of zinc deficiency on glucose metabolism in meal-fed rats. The British journal of nutrition. 1983;49(3):441-52. Epub 1983/05/01. doi: 10.1079/BJN19830053. PMID: 6860624; PMCID: PMC6860624.

27) Vallee BL, Falchuk KH. The biochemical basis of zinc physiology. Physiological reviews. 1993;73(1):79118. Epub 1993/01/01. doi: 10.1152/physrev.1993.73.1.79. PMID: 8419966.

28) DiSilvestro RA, Hart S, Marshall T, Joseph E, Reau A, Swain CB, et al. Enhanced aerobic exercise performance in women by a combination of three mineral Chelates plus two conditionally essential nutrients. The International Society of Sports Nutrition. 2017;14:42. Epub 2017/11/22. doi: 10.1186/s12970-017-0199-2. PMID: 29158726; PMCID: PMCPMC5683453. 
29) Chu A, Varma T, Petocz P, Samman S. Quantifiable effects of regular exercise on zinc status in a healthy population-A systematic review. PloS one. 2017;12(9):e0184827. Epub 2017/09/21. doi: 10.1371/journal.pone.0184827. PMID: 28931036; PMCID: PMCPMC5607172.

30) Mir SH, Mani V, Pal RP, Malik TA, Sharma H. Zinc in Ruminants: Metabolism and Homeostasis. The Proceedings of the National Academy of Sciences, India, Section B: Biological Sciences. 2018:1 -11. doi: 10.1007/s40011-018-1048-z.

31) Livingstone C. Zinc: physiology, deficiency, and parenteral nutrition. Nutrition in Clinical Practice. 2015;30(3):371-82. doi: 10.1177/0884533615570376.

32) Parrott J, Frank L, Rabena R, Craggs-Dino L, Isom KA, Greiman LJSfO, et al. American Society for Metabolic and Bariatric Surgery integrated health nutritional guidelines for the surgical weight loss patient 2016 update: micronutrients. Surgery for Obesity and Related Diseases. 2017;13(5):727-41. doi: 10.1016/j.soard.2016.12.018. PMCID: PMC28392254.

33) Lukaski HC. Magnesium, zinc, and chromium nutriture and physical activity-. The American journal of clinical nutrition. 2000;72(2):585S-93S. doi: 10.1093/ajen/72.2.585S. PMCID: PMC10919964.

34) Manore MM, Helleksen JM, Merkel J, Skinner JS. Longitudinal changes in zinc status in untrained men: effects of two different 12-week exercise training programs and zinc supplementation. Journal of the American Dietetic Association. 1993;93(10):1165-8. Epub 1993/10/01. doi: 10.1016/0002-8223(93)916538. PMID: 8409141.

35) Chu A, Holdaway C, Varma T, Petocz P, Samman SJSM. Lower Serum Zinc Concentration Despite Higher Dietary Zinc Intake in Athletes: A Systematic Review and Meta-analysis. Sports Medicine. 2018;48(2):327-36. doi: 10.1007/s40279-017-0818-8.

36) Åstrand P-O, Irma R. A Nomogram for Calculation of Aerobic Capacity (Physical Fitness) From Pulse Rate During Submaximal Work. Journal of applied physiology. 1954;7(2):218-21. doi: 10.1152/jappl.1954.7.2.218. PMID: 13211501.

37) Kenney WL, Wilmore JH, Costill DL. Physiology of Sport and Exercise. 6th ed: Human Kinetics; 2018.

38) Tarmast $D$. The effect of a progressive athletic activity up to exhaustion on the blood serum's concentration of two mineral materials ( $\mathrm{Fe}$ and $\mathrm{Zn}$ ) in two groups of basketball players and nonathletes. Journal of Science and Medicine in Sport. 2007;10:87. doi: 10.1016/S1440-2440(07)70260-8.

39) Hill DW. The relationship between power and time to fatigue in cycle ergometer exercise. International journal of sports medicine. 2004;25(5):357-61. Epub 2004/07/09. doi: 10.1055/s-2004-815838. PMID: 15241715.

40) George JD, Vehrs PR, Babcock GJ, Etchie MP, Chinevere TD, Fellingham GW. A Modified Submaximal Cycle Ergometer Test Designed to Predict Treadmill VO2max. Measurement in Physical Education and Exercise Science. 2000;4(4):229-43. doi: 10.1207/S15327841MPEE0404_3.

41) McArdle WD. Sports and Exercise Nutrition. 5th ed. North American: Lippincott Williams \& Wilkins; 2018.

42) VanValin KR, Genther-Schroeder ON, Carmichael RN, Blank CP, Deters EL, Hartman SJ, et al. Influence of dietary zinc concentration and supplemental zinc source on nutrient digestibility, zinc absorption, and retention in sheep. Journal of animal science. 2018;96(12):5336-44. Epub 2018/10/10. doi: 10.1093/jas/sky384. PMID: 30299509; PMCID: PMCPMC6276585.

43) Fraga CG, Oteiza PI, Keen CL. Trace elements and human health. Molecular aspects of medicine. 2005;26(4-5):233-4. Epub 2005/08/27. doi: 10.1016/j.mam.2005.07.014. PMID: 16122783.

44) Hambidge M. Biomarkers of trace mineral intake and status. The Journal of nutrition. 2003;133(3):948s55s. Epub 2003/03/04. doi: 10.1093/jn/133.3.948S. PMID: 12612181.

45) Donma MM, Donma OJTJoMS. Trace elements and physical activity in children and adolescents with depression. Turkish Journal of Medical Sciences. 2010;40(3):323-33. doi: 10.3906/sag-0811-33.

46) McClung JP, Murray-Kolb LE. Iron nutrition and premenopausal women: effects of poor iron status on physical and neuropsychological performance. Annual review of nutrition. 2013;33:271 -88. doi: 10.1146/annurev-nutr-071812-161205. PMCID: PMC23642204.

47) Yoshimura H, Inoue T, Yamada T, Shiraki K. Anemia during hard physical training (sports anemia) and its causal mechanism with special reference to protein nutrition. World review of nutrition and dietetics. 1980;35:1-86. Epub 1980/01/01. doi: 10.1159/000386405. PMID: 6994373; PMCID: PMC6994373.

48) de Wijn JF, de Jongste JL, Mosterd W, Willebrand D. Hemoglobin, packed cell volume, serum iron and iron binding capacity of selected athletes during training. The Journal of Sports Medicine and Physical Fitness. 1971;11(1):42-51. Epub 1971/01/01. doi: 10.1159/000175330. PMID: 5127155; PMCID: PMC5127155. 
49) Stewart JG, Ahlquist DA, McGill DB, Ilstrup DM, Schwartz S, Owen RA. Gastrointestinal blood loss and anemia in runners. Annals of internal medicine. 1984;100(6):843-5. Epub 1984/06/01. doi: 10.7326/00034819-100-6-843. PMID: 6609656; PMCID: PMC6609656.

50) Siegel AJ, Hennekens CH, Solomon HS, Van Boeckel B. Exercise-related hematuria. Findings in a group of marathon runners. Jama. 1979;241(4):391-2. Epub 1979/01/26. doi: 10.1001/jama.1979.03290300033023. PMID: 758557; PMCID: PMC758557.

51) Woodson RD, Wills RE, Lenfant C. Effect of acute and established anemia on O2 transport at rest, submaximal and maximal work. Journal of applied physiology: respiratory, environmental and exercise physiology. 1978;44(1):36-43. Epub 1978/01/01. doi: 10.1152/jappl.1978.44.1.36. PMID: 627497.

52) Gardner GW, Edgerton VR, Senewiratne B, Barnard RJ, Ohira Y. Physical work capacity and metabolic stress in subjects with iron deficiency anemia. The American journal of clinical nutrition. 1977;30(6):9107. Epub 1977/06/01. doi: 10.1093/ajcn/30.6.910. PMID: 868783.

53) McKay RH, Higuchi DA, Winder WW, Fell RD, Brown EB. Tissue effects of iron deficiency in the rat. Biochimica et Biophysica Acta (BBA) - General Subjects. 1983;757(3):352-8. Epub 1983/06/09. doi: 10.1016/0304-4165(83)90061-2. PMID: 6303441; PMCID: PMC6303441.

54) Finch CA, Miller LR, Inamdar AR, Person R, Seiler K, Mackler B. Iron deficiency in the rat. Physiological and biochemical studies of muscle dysfunction. Journal of Clinical Investigation. 1976;58(2):447-53. Epub 1976/08/01. doi: 10.1172/jci108489. PMID: 956378; PMCID: PMCPMC333200.

55) Holdaway CR. Zinc status of athletes compared to non-athletes: University of Otago; 2017.

56) Dressendorfer RH, Sockolov R. Hypozincemia in Runners. The Physician and sportsmedicine. 1980;8(4):97-100. Epub 1980/04/01. doi: 10.1080/00913847.1980.11710918. PMID: 27432710.

57) Córdova A, Navas FJJAon, metabolism. Effect of training on zinc metabolism: changes in serum and sweat zinc concentrations in sportsmen. Annals of Nutrition and Metabolism. 1998;42(5):274-82. doi: $10.1159 / 000012744$.

58) Arikan S, Akkus H, Halifeoglu I, Baltaci AKJCB, biochemistry FC, disease imbaao. Comparison of plasma leptin and zinc levels in elite athletes and sedentary people. Cell Biochemistry and Function. 2008;26(6):655-8. doi: 10.1002/cbf.1480. PMCID: PMC18570187.

59) Haralambie G. Serum zinc in athletes in training. International journal of sports medicine. 1981;2(03):1358. doi: 10.1055/s-2008-1034599.

60) Lukaski HC. Low dietary zinc decreases erythrocyte carbonic anhydrase activities and impairs cardiorespiratory function in men during exercise-. The American journal of clinical nutrition. 2005;81(5):1045-51. doi: 10.1093/ajcn/81.5.1045.

61) Van Loan MD, Sutherland B, Lowe NM, Turnlund JR, King JC. The effects of zinc depletion on peak force and total work of knee and shoulder extensor and flexor muscles. International Journal of Sport Nutrition. 1999;9(2):125-35. doi: 10.1123/ijsn.9.2.125. PMCID: PMC10362450.

62) Keen C, Hackman R, editors. Trace elements in athletic performance. Sport, Health and Nutrition: 1984 Olympic Scientific Congress Proceedings; 1986. Champaign, Ill: Human Kinetics.

63) Solomons NW. Competitive interaction of iron and zinc in the diet: consequences for human nutrition. The Journal of nutrition. 1986;116(6):927-35. Epub 1986/06/01. doi: 10.1093/jn/116.6.927. PMID: 3522825. 